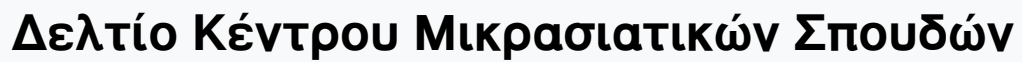

Tóp. 3 (1982)

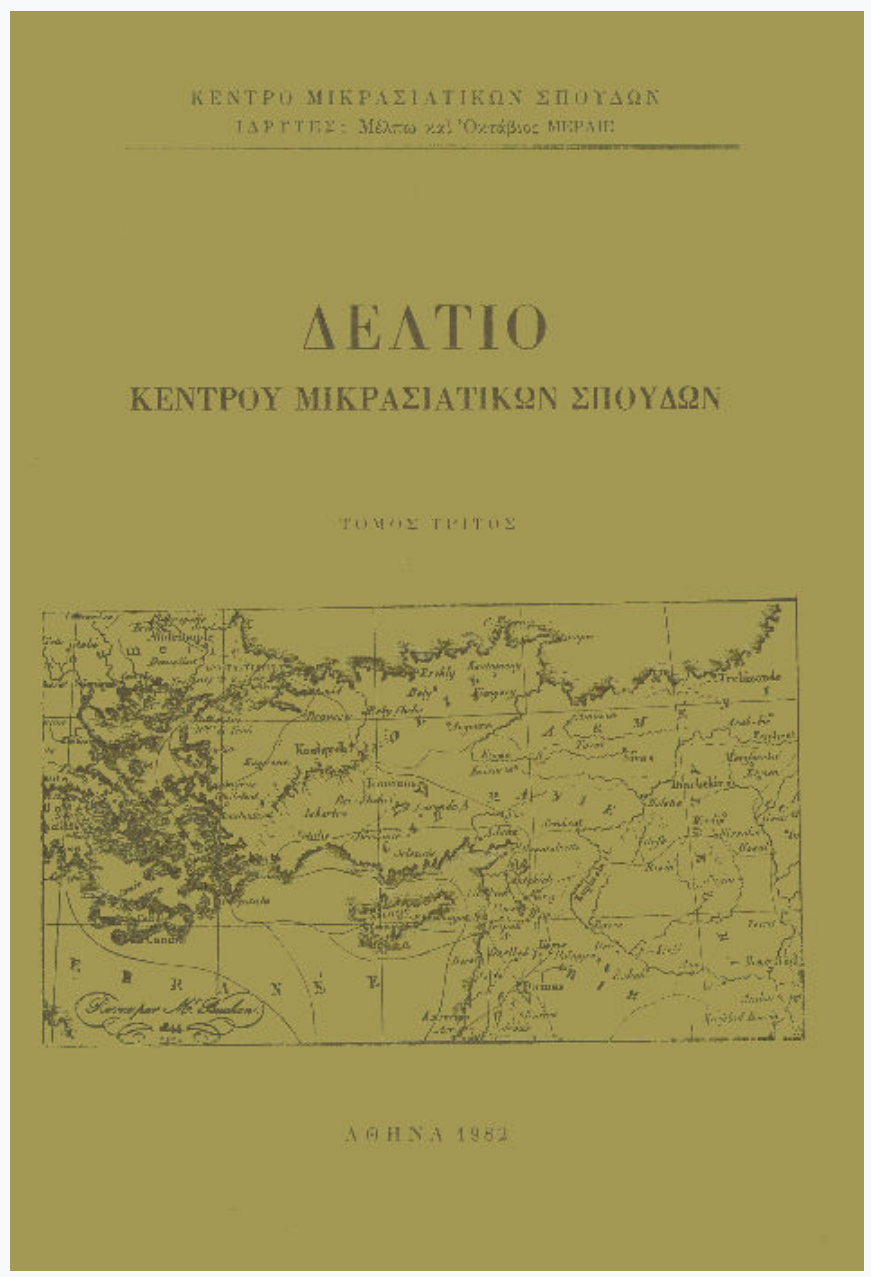

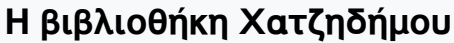

I. $\Pi$.

doi: $10.12681 /$ deltiokms.292

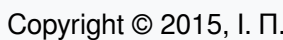

\section{(C) (1)Q(-)}

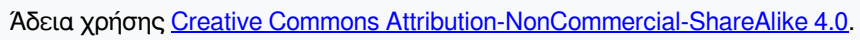

\section{Bıß入ıорачıкń avaчopá:}

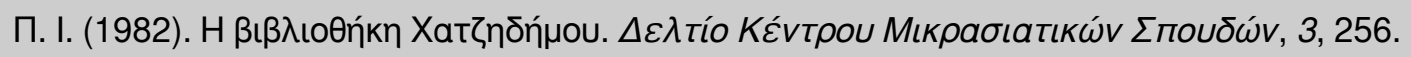
https://doi.org/10.12681/deltiokms.292 


\section{XPONIKA}

\section{H BIBAIO@HKH XATZHAHMO}

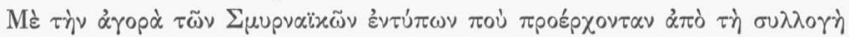

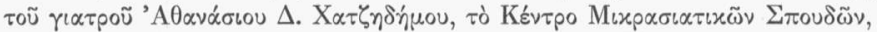

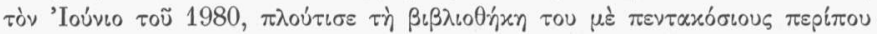

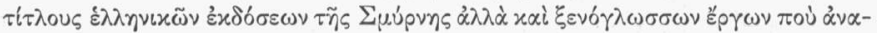

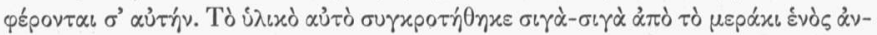

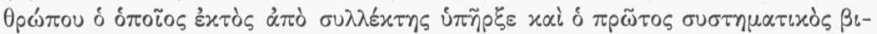

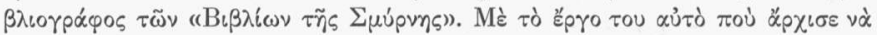

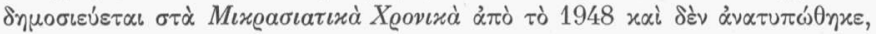

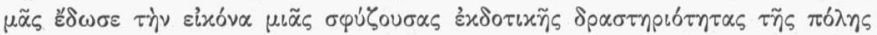

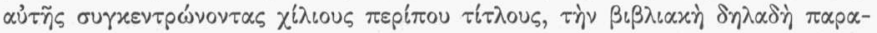

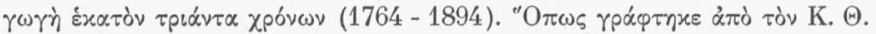

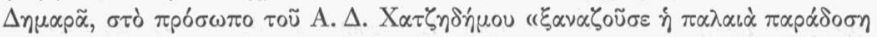

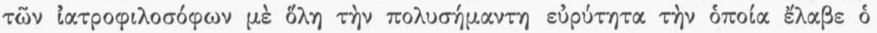

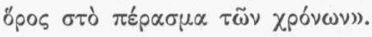

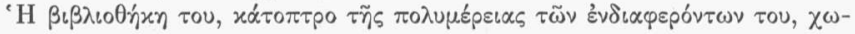

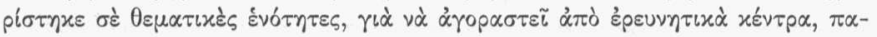

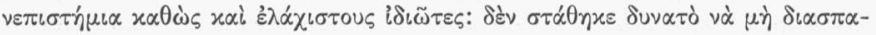

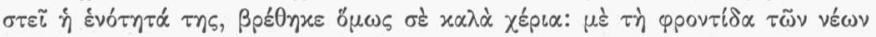

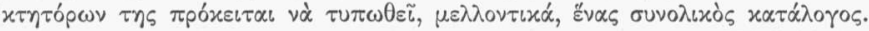

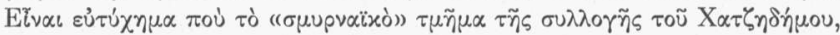

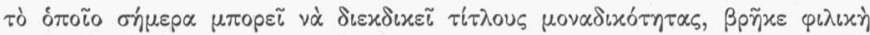

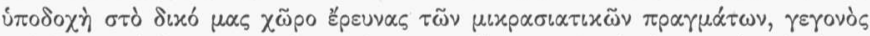

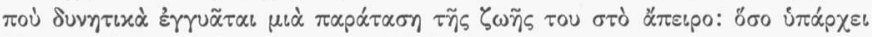

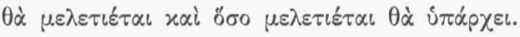

I. $\Pi$. 